EGU2020-17652

https://doi.org/10.5194/egusphere-egu2020-17652

EGU General Assembly 2020

(c) Author(s) 2021. This work is distributed under

the Creative Commons Attribution 4.0 License.

\title{
Paleoenvironmental changes, climate and human impact in the Western Mediterranean Sea during the 4.2 Kyr event along a North- South Transect
}

Nathalie Combourieu-Nebout ${ }^{1}$, Vincent Coussin ${ }^{2}$, Yannick Miras ${ }^{1}$, Aurélie Penaud ${ }^{2}$, Sandra Picard Casall $^{1}$, Odile Peyron ${ }^{3}$, Bassem Jalali ${ }^{4}$, Marie-Alexandrine Sicre ${ }^{5}$, Nathalie Babonneau ${ }^{1}$, and Antonio Cattaneo ${ }^{6}$

${ }^{1}$ HNHP, UMR 7194 CNRS/MNHN, Paris, France (nneboutcombourieu@mnhn.fr)

${ }^{2}$ Univ. Brest, IUEM, UMR 6538 LGO Laboratoire Géosciences Océan, CNRS, 29280, Plouzané, France.

${ }^{3}$ ISEM, UMR 5554 CNRS, Université de Montpellier, 34095 Montpellier, France.

${ }^{4}$ LOCEAN, UMR 7159 CNRS/IRD/Sorbonne Université/MNHN, Institut Pierre Simon Laplace, 4 place Jussieu, 75252 Paris,

France.

${ }^{5}$ Key Laboratory of Marine Ecosystem and Biogeochemistry, Second Institute of Oceanography, MNR, Hangzhou 310012, P.

R. China.

${ }^{6}$ IFREMER, Géosciences Marines, Technopôle Brest-Iroise, 292280 Plouzané, France.

The $4.2 \mathrm{ka}$ event is considered a key-period of the Mediterranean climate because of its potential impact on human societies over the Holocene. Numerous records provide a detailed description on its expression in continental and marine archives (e.g. Bini et al, 2019). They generally indicate cold/dry conditions, although not uniformly expressed across the Mediterranean, and summer dryness reinforced by dry winters. Palynological data from the central Mediterranean basin show a complex response of the vegetation during this climatic event that seems to be more pronounced in the southern sites.

In this study, we developed a multidisciplinary approach on two sequences collected in the Western Mediterranean Sea to insight the response of the W-Mediterranean forest along a NorthSouth transect. The two marine records, KSGC-31 $\left(43^{\circ} \mathrm{N}-3^{\circ} 17.9^{\prime} \mathrm{E} ; 60 \mathrm{~m}\right.$ water depth, Gulf of Lion margin at $20 \mathrm{~km}$ from the coast) and MD04-2801 (36 30.99' N-0 0 30.03' W, $2067 \mathrm{~m}$ water depth, $12 \mathrm{~km}$ from the Algerian coast) were used to document regional changes in the basin between 5 and $3 \mathrm{kyr}$ BP at a multi-decadal to centennial scale temporal resolution.

Information derived from palynological (pollen, spores, dinocysts, microalgae and non-pollen palynomorphs) and marine proxy data (alkenone-derived SSTs, isotopes...) are combined to evaluate environmental and hydrological changes and how this relate to human activities. Our findings highlight coherent climatic patterns and time-lags along a South-North transect in the Western Mediterranean during the establishment of droughts. They also reveal the first indications of human impact in the two areas. Overall, our study shows the effectively of our approach based on cross-analysis of continental palynological and marine evidences to decipher the chronology of sequence of events embedded in multiproxy records. 
Bini, M., Zanchetta, G., Perşoiu, A., et al. : The $4.2 \mathrm{ka}$ BP Event in the Mediterranean region: an overview, Clim. Past, 15, 555-577, https://doi.org/10.5194/cp-15-555-2019, 2019. 